\title{
Prevalence of low bone mineral density in adolescents and adults with cystic fibrosis
}

\author{
Roberta Vanacor ${ }^{1}$, Fabiana V. Raimundo ${ }^{1}$, Natália A. Marcondes ${ }^{1}$, Bruno P. Corte ${ }^{2}$, Aline M. Ascoli ${ }^{2}$, Aline Z. de Azambuja ${ }^{2}$,
} Luciano Scopel ${ }^{2}$, Patrícia V. dos Santos ${ }^{2}$, Paulo T. R. Dalcin ${ }^{3}$, Gustavo A. M. Faulhaber ${ }^{2}$, Tânia W. Furlanetto ${ }^{2}$

1-Postgraduate Program in Medicine, Medical Sciences - Federal University of Rio Grande do Sul, Porto Alegre, RS, Brazil
2- Division of Internal Medicine, Hospital de Clínicas de Porto Alegre - Federal University of Rio Grande do Sul, Porto Alegre, RS, Brazil
3-Division of Pneumology, Hospital de Clínicas de Porto Alegre - Federal University of Rio Grande do Sul, Porto Alegre, RS, Brazil

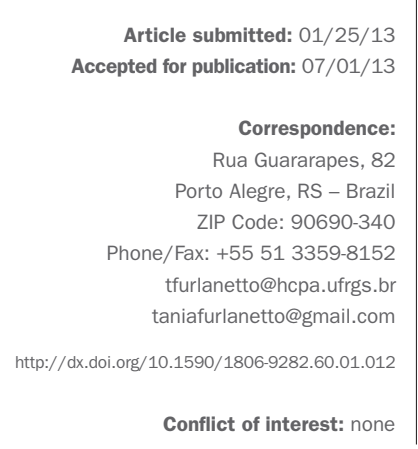

Article submitted: 01/25/13 Correspondence: Rua Guararapes, 82 orto Alegre, RS - Brazil ax: +55 51 3359-8152 tfurlanetto@hcpa.ufrgs.br

\section{SUMmarY}

Objective: The aim of this cross-sectional study was to evaluate the prevalence of low bone mass density in cystic fibrosis patients as well as to evaluate the factors associated with bone mass in such patients.

Methods: Bone mass density was measured by dual-photon X-ray absorptiometry of lumbar spine (L1-L4), in patients $\leq 19$ years old, or lumbar spine and femur (total and neck) in patients $\geq 20$ years old. Evaluations of nutritional status, biochemical parameters, and lung function were performed. Medication data were obtained from medical records.

Results: Fifty-eight patients were included in the study ( 25 males/ 33 females), mean age 23.9 years (16-53years). The prevalence of bone mass below the expected range for age at any site was $20.7 \%$. None of the subjects had history of fracture. Lumbar spine $Z$-score in cystic fibrosis patients correlated positively with body mass index $(\mathrm{r}=0.3, \mathrm{p}=0.001)$, and forced expiratory volume in the first second (\% predicted) $(\mathrm{r}=0.415, \mathrm{p}=0.022)$. Mean lumbar spine $\mathrm{Z}$-score was higher in women $(\mathrm{p}=0.001)$, in patients with no pancreatic insufficiency $(\mathrm{p}=0.032)$, and in patients with no hospitalization in the last 3 months $(\mathrm{p}=0.02)$. After multivariate analysis, body mass index $(\mathrm{p}=0.001)$ and $\operatorname{sex}(\mathrm{p}=0.001)$ were independently associated with $Z$-score in lumbar spine.

Conclusion: Low bone mass is a frequent problem in patients with CF, being independently associated with body mass index, and male sex.

Key words: cystic fibrosis, bone, bone density, bone loss, bone diseases, metabolic, risk factors.

\section{INTRODUCTION}

Advances in the care of patients with cystic fibrosis (CF) increased survival. Bone health is important for the quality of life in aging patients, and became more relevant in patients affected with $\mathrm{CF}^{1-4}$.

Several studies described lower bone mass density (BMD) in patients with $\mathrm{CF}$, which increases fracture risk ${ }^{5-8}$. Bone fractures can cause pain, decrease respiratory status, and are a contraindication for lung transplantation in these patients ${ }^{9,10}$.

Cross-sectional studies in adults (age range from 16-60 years) with CF demonstrated that 6 to $68 \%$ had $\mathrm{Z}$-scores $\leq-2.0^{8,11-16}$. Therefore, understanding the me- chanisms of low BMD in CF patients is important to improve its prevention and treatment. Abnormal calcium homeostasis, poor nutritional status, chronic inflammation, or inactivity associated with lung infection exacerbations could be responsible for bone abnormality $y^{5,8,12,17-19}$. Low BMD has been independently associated with malnutrition, male sex, $\cdot$ F508 mutation, and severe lung injury ${ }^{14}$. Other potential risk factors described were use of glucocorticosteroids, hypogonadism, decreased physical activity, malabsorption of calcium and vitamins, chronic infections, and inflammatory cytokines ${ }^{5,8,11,17,18,20-23}$. 
In Brazil, just one study evaluated the prevalence of low $\mathrm{BMD}$ in patients with $\mathrm{CF}^{24}$. As bone mass is dependent on ethnic factors ${ }^{25}$ and the prevalence of CFTR gene mutations is not the same in different populations ${ }^{26,27}$, it is important to study how bone mass is affected in patients with cystic fibrosis in different regions of the world. Therefore, the aim of this study was to evaluate the prevalence of low BMD in CF patients in a tertiary care facility in Porto Alegre, state of Rio Grande do Sul, Brazil, $\left(30^{\circ} \mathrm{S}\right)$ as well as to evaluate the factors associated with low bone mass in these patients.

\section{Methods}

The study was carried out in the outpatient program for adolescents and adults with $\mathrm{CF}$ at the Hospital de Clínicas de Porto Alegre (HCPA), from February $25^{\text {th }}$ to September $23^{\text {th }}, 2011$, after approval by the institution's Ethics Committee. Each patient gave written consent before inclusion in the study.

\section{Inclusion criteria}

Patients 16 years old or older with CF confirmed by sweat test $(\mathrm{Cl} \geq 60 \mathrm{mEq} / \mathrm{L})$ in two occasions or CFRT gene mutation in both alleles were included.

Exclusion criteria: Organ transplant.

Experimental design: Cross-sectional study. Data were obtained in the medical records and during interviews with the patients.

\section{Evaluation of BMD}

BMD was measured by dual-photon X-ray absorptiometry (DXA), with HOLOGIC QDR4500A, equipped with standard density software (version 8.26) (4500 Acclaim densitometer, Hologic, Wattham, MA, USA). Regions evaluated were lumbar spine, L1- L4, in patients $\leq 19$ years old, or lumbar spine and femur (total and neck) in patients $\geq 20$ years old. Bone mass below the expected range for age was defined by $Z$-score as $\leq-2.0$ in premenopausal women and in men $\leq 50$ years old. Osteoporosis was diagnosed when the T-score was $\leq-2.5$ in perimenopausal or postmenopausal women or men $>50$ years old ${ }^{28,29}$.

\section{Evaluation of nutritional status and biochemical parameters}

The nutritional status was evaluated by weight, height, and body mass index (BMI). In patients $<20$ years old, BMI $\geq$ percentile 50 for age and sex was considered appropriate; in patients $>20$ years BMI was considered appropriate when it was $\geq 22 \mathrm{~kg} / \mathrm{m}^{2}$ for women and $\geq 23 \mathrm{~kg} / \mathrm{m}^{2}$ for $\mathrm{men}^{30,31}$. Calcium ingestion was estimated by food frequency questionnaire. Serum samples were stored at $-80^{\circ} \mathrm{C}$, until measurements in the same assay run. Serum C-reactive protein (CRP), calcium, phosphate, magnesium, and albumin levels were measured by routine methods. Serum $25(\mathrm{OH})$ vitamin D $[25(\mathrm{OH}) \mathrm{D}]$ and parathyroid hormone (PTH) levels were measured, respectively, by chemiluminiscence method (Liaison ${ }^{\circledR}$, Diasorin, Stillwater, MN, USA; intrassay coefficient of variation of 5.5\%), and by sandwich immunoassay to Intact PTH (iPTH, Siemens, Tarrytown, NY, USA; intrassay coefficient of variation 5.2\%).

\section{Evaluation of lung function}

Lung function was evaluated through spirometry (Jaeger, Version 4.34, Würzburg, BY, Germany). Forced vital capacity (FVC), forced expiratory volume in the first second $\left(\mathrm{FEV}_{1}\right)$ and $\mathrm{FEV}_{1} / \mathrm{FVC}$ were measured three times, and the best result was registered. All parameters were reported as absolute values and as percent of predicted for normal values ${ }^{32}$. The number of exacerbations and hospital admissions in the last year was determined. The assessment of the CF clinical severity and chest radiological severity were scored by a trained pulmonologist physician using the Shwachman-Kulczycki score (SK) ${ }^{33}$, and the score of Brasfield ${ }^{34}$. Data from lung bacteria were collected.

\section{Pharmacologic treatment}

Medications in use were obtained from medical files and adherence to medications was confirmed during medical appointments.

\section{Statistical analysis}

The prevalence of bone mass below the expected range for age, and osteoporosis were calculated. Factors associated with the $Z$-score in the lumbar spine were evaluated by the correlation tests of Pearson or Spearman, Student $t$ or Mann-Whitney tests, when indicated. Backwards multiple linear regression, including factors associated with lumbar $Z$-score with $\mathrm{p}<0.2$, was performed to identify factors independently associated to it. All calculations were made in SPSS Software 16.0 (Chicago, IL, EUA).

\section{Results}

Sixty-nine patients were eligible, and 58 agreed to participate and were included in the study. Their baseline characteristics are shown in Table 1 .

All patients had clinical aspects compatible with CF. The diagnosis was confirmed by sweat test in 53 (91\%) patients which had at least two positive test results; in five (9\%) patients, the diagnosis was established by CFTR gene abnormalities. CFTR gene testing was performed in 33 (57\%) patients: 8 (24\%) were homozygous for $\cdot$ F50 $5 \mathrm{mu}-$ tation, 23 (70\%) were compound heterozygotes, and two (6\%) had no identified abnormality. 
TABLE 1 Baseline characteristics of cystic fibrosis patients $(n=58)$

\begin{tabular}{|c|c|}
\hline Age (years) & $23.9 \pm 7.6$ \\
\hline Male/Female & $25 / 33$ \\
\hline Weight (kg) & $58.7 \pm 10.5$ \\
\hline Height (m) & $1.7 \pm 0.07$ \\
\hline $\mathrm{BMI}\left(\mathrm{kg} / \mathrm{m}^{2}\right)$ & $21.2 \pm 3.5$ \\
\hline Estimated daily calcium ingestion (mg) & $1466(898 / 2360)$ \\
\hline Serum albumin $(\mathrm{g} / \mathrm{dL})$ & $4.5 \pm 0.27$ \\
\hline Serum calcium $(\mathrm{mg} / \mathrm{dL})$ & $9.4 \pm 0.27$ \\
\hline Serum phosphate $(\mathrm{mg} / \mathrm{dL})$ & $4.2 \pm 0.53$ \\
\hline Serum magnesium (mg/dL) & $2.1 \pm 0.13$ \\
\hline Serum PTH (pg/mL) & $33.9 \pm 18.1$ \\
\hline Serum $25(\mathrm{OH})$ vitamin $\mathrm{D}(\mathrm{ng} / \mathrm{mL})$ & $28.5 \pm 11.0$ \\
\hline Serum C-reactive protein (mg/L) & $9.8(<4 / 29.1)$ \\
\hline $\mathrm{FVC}(\mathrm{L})$ & $2.99 \pm 1.1$ \\
\hline FVC ( \% predicted) & $71.9 \pm 25.6$ \\
\hline FEV1(\% predicted) & $60.59 \pm 28.84$ \\
\hline FEV1/FVC & $69.85 \pm 15.83$ \\
\hline Shwachman-Kulczycki score & $77.0 \pm 15.2$ \\
\hline Brasfield score & $16.9 \pm 5.1$ \\
\hline Number of lung exacerbations in 12 months & $2(0 / 3)$ \\
\hline Hospitalizations in the last month, $\mathrm{n}(\%)$ & $3(5.2)$ \\
\hline Hospitalizations in the last three months, $\mathrm{n}(\%)$ & $10(17.2)$ \\
\hline Hospitalizations in the last year, n (\%) & $17(29.3)$ \\
\hline Pancreatic exocrine insufficiency, n (\%) & $42(72)$ \\
\hline Diabetes mellitus, n (\%) & $8(13.8)$ \\
\hline
\end{tabular}

Data are shown as mean \pm SD, or median (percentile25/75), or number $(n)$;

BMI: Body mass index; PTH: parathyroid hormone; FVC: Forced vital capacity;

FEV1: Forced expiratory volume in $1 \mathrm{~s}$.

All patients with pancreatic insufficiency were treated with pancreatic enzymes and vitamins $A, D, E$, and $K$, and seven patients received calcium supplementation. Three
(9.1\%) women were using oral contraceptive. All women had normal menstrual periods, except one that had already undergone menopause.

Inhaled corticosteroid therapy was used by $17 \mathrm{pa}-$ tients $(29.3 \%)$, and none used oral glucocorticosteroids. $S$. aureus, $P$. aeruginosa and $B$. cepacia were present in respectively, $45(77.6 \%), 33(56.9 \%)$, and $13(22.4 \%)$ of the patients. Sixteen patients $(28 \%)$ had severe lung disease with FEV1 predicted below 40\%. According to the Shwachman-Kulczycki score, 37 (64\%) of the patients were in good or excellent clinical condition.

BMD was assessed in the lumbar spine (L1-L4) in 58 patients; it was also measured in the proximal femur (total and neck) in 38 patients aged 20 years or more. The prevalence of bone mass below the expected range for age, $Z$ -score $<-2.0$, at any site was $20.7 \%$ (9 males and 3 females); 9 patients were $\geq 20$ years, so BMD was assessed in lumbar spine and proximal femur: 5 had low BMD only in L1-L4, one had low BMD only in proximal femur, and three had low BMD in both. One of the patients, a 53-year old postmenopausal woman, had osteoporosis. None of the subjects had history of fracture, and no vertebral fracture was described in the lateral chest X-ray. The mean Z-score for lumbar spine was $-0.93 \pm 1.2$, ranging from 1.6 to -3.2 .

Serum total testosterone, bioavailable testosterone, and estradiol levels were measured in all male patients, and the means were, respectively, $4.7 \pm 2.1 \mathrm{ng} / \mathrm{mL}, 2.1 \pm 0.82 \mathrm{ng} /$ $\mathrm{mL}$, and $29 \pm 14.2 \mathrm{pg} / \mathrm{mL}$. Serum estradiol was positively correlated with serum testosterone levels $(\mathrm{r}=0.550, \mathrm{p}=0.004)$, and bioavailable testosterone levels $(\mathrm{r}=0.477, \mathrm{p}=0.016)$.

Lumbar spine Z-score in CF patients correlated positively with BMI, and with FEV1 (\% predicted), and mean lumbar spine $Z$-score was higher in women, in patients

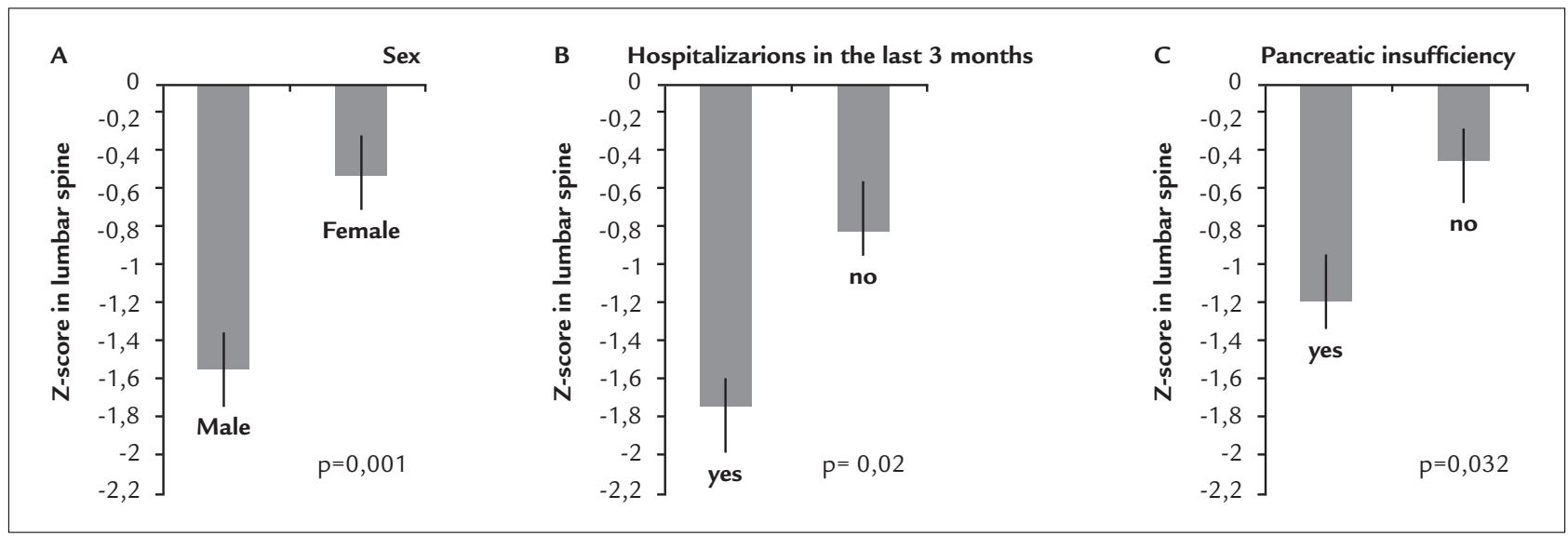

FIGURE 1 Mean lumbar spine Z-score in patients with cystic fibrosis and its association with sex (A), hospitalization in the last 3 months (B), and pancreatic insufficiency $(C)$. Data are shown as mean \pm standard error of the mean. 
with no pancreatic insufficiency, and in patients with no hospitalization in the last 3 months, as shown in Figure 1.

There was a positive correlation between lumbar Z-score and BMI $(\mathrm{r}=0.420, \mathrm{p}=0.001)$ and lumbar $\mathrm{Z}$-score and predicted FEV1(\%) $(\mathrm{r}=0.300, \mathrm{p}=0.02)$. There was no correlation of lumbar $Z$-score and age $(\mathrm{r}=-0.199, \mathrm{p}=0.134)$, predicted FEV1(\%)/FVC ratio $(\mathrm{r}=0.193, \mathrm{p}=0.147)$, SK score $(\mathrm{r}=0.202, \mathrm{p}=0.129)$, Brasfield score $(\mathrm{r}=0.041, \mathrm{p}=0.762)$, serum albumin $(\mathrm{r}=0.055, \mathrm{p}=0.681), \mathrm{CRP}(\mathrm{r}=-0.165, \mathrm{p}=0.732)$, calcium $(\mathrm{r}=0.046, \mathrm{p}=0.216)$, phosphate $(\mathrm{r}=-0.063, \mathrm{p}=0.638)$, magnesium $(\mathrm{r}=-0.036, \mathrm{p}=0.638)$, PTH $(\mathrm{r}=0.005, \mathrm{p}=0.971)$, and $25(\mathrm{OH}) \mathrm{D}(\mathrm{r}=-0.181, \mathrm{p}=0.173)$ levels, estimated calcium ingestion $(r=-0.049, p=0.716)$, and lung exacerbations in 12 months $(\mathrm{r}=0.053, \mathrm{p}=0.694)$.

Mean lumbar spine $Z$-score were similar in patients taking omeprazole $(-1.29 \pm 1.25 ; \mathrm{n}=10)$ or not $(-0.82 \pm 1.16$; $\mathrm{n}=48), \mathrm{p}=0.255$; using inhaled glucocorticosteroid $(-0.74 \pm 1.14 ; \mathrm{n}=17)$ or $\operatorname{not}(-1.01 \pm 1.21 ; \mathrm{n}=41), \mathrm{p}=0.421$; with bacterial colonization for $P$. aeruginosa $(-0.97 \pm 1.1, \mathrm{n}=33)$ or not $(-0.89 \pm 1.33 ; \mathrm{n}=25), \mathrm{p}=0.806 ;$ B. cepacea $(-0.85 \pm 1.04$, $\mathrm{n}=13))$ or not $(-0.96 \pm 1.24, \mathrm{n}=45), 0.769 ; S$. aureus $(-0.86 \pm 1.08, \mathrm{n}=45)$ or $\operatorname{not}(-1.20 \pm 1.52, \mathrm{n}=13) \mathrm{p}=0.344$; with diabetes mellitus $(-1.55 \pm 1.16, n=8)$ or not $(-0.83 \pm 1.8, n=50)$, $\mathrm{p}=0.115$; with hospitalization in the last year $(-1.30 \pm$ $1.2, \mathrm{n}=17)$ or $\operatorname{not}(-0.78 \pm 1.17, \mathrm{n}=41), \mathrm{p}=0.126$; and with hospitalization in the last month $(-1.47 \pm 1.4, n=3)$ or not $(-0.90 \pm 1.19, \mathrm{n}=55), \mathrm{p}=0.430$.

Multivariate stepwise backwards analysis revealed that BMI $(\mathrm{p}=0.001)$, and $\operatorname{sex}(\mathrm{p}=0.001)$ were independently associated with lumbar spine Z-score (Table 2 ).

\section{TABLE 2 Factors independently associated with lumbar} spine Z-score by multivariate stepwise backwards analysis

\begin{tabular}{l|l|l|l|l} 
& B & Standard Error & Beta & $P$ \\
\hline Z-score & & & & \\
\hline Sex & 0.970 & 0.262 & 0.406 & 0.001 \\
\hline BMI & 0.135 & 0.37 & 0.397 & 0.001
\end{tabular}

Included in the model: Sex, BMI, FEV1 \% predicted, number of hospitalizations in the last three months, pancreatic insufficiency and serum 25-hydroxyvitamin D levels.

\section{Discussion}

In the present study, $20.7 \%$ of the adolescent and adult CF outpatients had bone mass below the expected range for age (Z-score $\leq 2.0$ in lumbar spine and/or femur). In the univariate analysis, $Z$-score in lumbar spine was associated with sex, BMI, FEV1 (\% predicted), FVC\%, number of hospitalizations in the last three months, and pancreatic insufficiency. After multivariate regression analysis including all the above, except $\mathrm{CFV} \%$, due to its strong association with FEV1(\%predicted), and serum $25(\mathrm{OH})$ levels, only sex and BMI were independently associated with $Z$-score in lumbar spine.

The prevalence of bone mass $Z$-score $<-2.0$ in lumbar spine was $14.6 \%$, in the patients studied by Lucidi et al ${ }^{37}$, and $25 \%$ in the patients studied by Dodd et al ${ }^{12}$; these small differences could be due to age, and clinical conditions of patients in different series. Lower prevalence of low bone mass in lumbar spine $(1 / 17)$ was described by Street et al ${ }^{13}$, but it cannot be excluded that this result was due the small size of the sample. Despite the high prevalence of low bone mass, no fractures were observed in our study. As fractures were evaluated by history and routine lateral chest radiography in our patients, the prevalence of fractures could have been underestimated.

Other studies described the prevalence of low bone mass in any site, lumbar spine, total body and femoral neck and/or total femur, despite of age below 20 years, and found higher prevalence from $23 \%$ to $68 \% 12,15,16,18$, ${ }^{38-41}$. Proximal femur BMD measurement is not considered appropriate for measurement of bone mass before skeletal maturity, because of higher variability and lack of reproducibility in this age group ${ }^{35,36}$.

Some factors have been associated with bone mass, like poor growth, delayed maturation, malnutrition, muscle deficits, decreased physical activity, chronic inflammation, and use of medications such as glucocorticoids ${ }^{2}$.

Several studies evaluated $Z$-score in lumbar spine and factors possibly associated with it $5,6,8,12-14,17,21,23,24,37,39,41$, ${ }^{42}$, nevertheless, some did not assess confounding. Positive factors independently associated with bone mass in lumbar spine were BMI, FEV1 (\% predicted), fat mass, body weight, age of puberty, body cell mass in children and adolescents, SK score and serum leptin ${ }^{5,6,8,14,23,39,42}$. Negative factors independently associated with bone mass were deltaF508, male sex, log of serum alkaline phosphatase, enteral nutrition, number of days of hospitalization in the last year, number of hospital admissions in the last year, physical activity score, oral/inhaled corticosteroids ${ }^{14,17,23,39}$. Probably all those factors reflected disease intensity, except for male sex. Why male subjects with CF had lower bone mass is unknown.

Haworth et al also found BMD significantly lower in men, despite comparable lung function, nutritional indices, and no evidence of male hypogonadism ${ }^{40}$. In our male subjects, there was no association between Z-score in lumbar spine with serum total testosterone levels, nor serum bioavailable testosterone levels, so hypogonadism probably was not contributing to low bone mass. Acquired aromatase deficiency could have occurred in these male pa- 
tients, as described in another infectious disease ${ }^{43}$, but all patients had serum estradiol levels in the normal range.

Of the nutritional factors associated with bone mass, the most important are vitamin $\mathrm{D}$, calcium ingestion, and $\mathrm{BMI}^{4}$. Although $25(\mathrm{OH}) \mathrm{D}$ was below $30 \mathrm{ng} / \mathrm{mL}$ in $60.3 \%$ of the patients (data not shown), there was no independent association between lumbar spine $Z$-score and serum $25(\mathrm{OH}) \mathrm{D}$ levels.

Glucocorticoids can decrease bone mass, when administered by the nasal route, if the amount absorbed is enough for systemic effects ${ }^{44}$. In our study, there was no association of inhaled steroids use with lumbar spine $Z$ -score, as described previously ${ }^{13,37}$, probably due to low dose and/or low absorption in these patients. Importantly, none of our patients used oral corticosteroids.

\section{Conclusion}

Low bone mass is a frequent problem in patients with CF, being associated with BMI, and male sex.

\section{Resumo}

Prevalência de densidade mineral óssea baixa em adolescentes e adultos com fibrose cística.

Objetivo: Determinar a prevalência de massa óssea baixa em pacientes adolescentes e adultos com fibrose cística e estudar os fatores potencialmente associados.

Métodos: Densidade mineral óssea foi determinada por absorciometria por dupla emissão de raios $\mathrm{X}$ na coluna lombar em pacientes $\leq 19$ anos e na coluna e no fêmur em pacientes $\geq 20$ anos. Avaliações nutricionais, bioquímicas e pulmonares foram realizadas. Dados referentes ao tratamento farmacológico foram coletados.

Resultados: 58 pacientes foram incluídos no estudo (25 homens/33 mulheres), média de idade de 23,9 anos (1653). Massa óssea abaixo da esperada foi verificada em $20,7 \%$ dos pacientes. Não houve histórico de fratura. Z-score da coluna lombar associou-se positivamente com índice de massa corporal $(\mathrm{r}=0,3 ; \mathrm{p}=0,022)$, volume expiratório forçado (\% previsto) $(\mathrm{r}=0,415 ; \mathrm{p}=0,001)$. A média do $Z$-score da coluna foi mais alta nas mulheres que nos homens $(p=0,001)$, em pacientes que não possuíam insuficiência pancreática $(\mathrm{p}=0,02)$ e em pacientes que não haviam sido hospitalizados nos últimos três meses $(\mathrm{p}=0,032)$. Os fatores encontrados como preditores independentes de $Z$-score da coluna lombar foram sexo masculino ( $\mathrm{p}=0,001)$ e índice de massa corporal $(\mathrm{p}=0,001)$.

Conclusão: Massa óssea baixa é frequente em pacientes com FC, estando associada independentemente com índice de massa corporal e sexo masculino.
Unitermos: fibrose cística, densidade óssea, massa óssea, perdas ósseas, doenças ósseas.

\section{Acknowledgments}

This work was supported by the Incentive Fund for Research and Events of the Hospital de Clínicas de Porto Alegre, Porto Alegre, RS, Brazil, and the National Council of Research, Brazil.

\section{REFEREnCES}

1. Buzzetti R, Salvatore D, Baldo E, Forneris MP, Lucidi V, Manunza D, et al. An overview of international literature from cystic fibrosis registries: 1 . Mortality and survival studies in cystic fibrosis. J Cyst Fibros. 2009;8:229-37.

2. Aris RM, Merkel PA, Bachrach LK, Borowitz DS, Boyle MP, Elkin SL, et al. Guide to bone health and disease in cystic fibrosis. J Clin Endocrinol Metab. 2005;90:1888-96

3. UK Cystic Fibrosis Trust Bone Mineralisation Working Group; 2007. [cited 2012 Mar 27]. Available form: http://www.cftrust.org.uk/aboutcf/ publications/consensusdoc/Bone-Mineral-Booklet.pdf

4. Sermet-Gaudelus I, Bianchi ML, Garabedian M, Aris RM, Morton A, Hardin DS, et al. European cystic fibrosis bone mineralisation guidelines. J Cyst Fibros. 2011;10(Suppl 2):S16-23.

5. Legroux-Gerot I, Leroy S, Prudhomme C, Perez T, Flipo RM, Wallaert B, et al. Bone loss in adults with cystic fibrosis: prevalence, associated factors, and usefulness of biological markers. Joint Bone Spine. 2012;79:73-77.

6. Rossini M, Del Marco A, Dal Santo F, Gatti D, Braggion C, James G, et al Prevalence and correlates of vertebral fractures in adults with cystic fibrosis. Bone. 2004;35:771-6.

7. Wolfenden LL, Judd SE, Shah R, Sanyal R, Ziegler TR, Tangpricha V. Vitamin $\mathrm{D}$ and bone health in adults with cystic fibrosis. Clin Endocrinol (Oxf). 2008;69:374-81.

8. Elkin SL, Fairney A, Burnett S, Kemp M, Kyd P, Burgess J, et al. Vertebral deformities and low bone mineral density in adults with cystic fibrosis: a cross-sectional study. Osteoporos Int. 2001;12:366-72.

9. Paccou J, Zeboulon N, Combescure C, Gossec L, Cortet B. The prevalence of osteoporosis, osteopenia, and fractures among adults with cystic fibrosis: a systematic literature review with meta-analysis. Calcif Tissue Int. 2010;86:1-7.

10. Spira A, Gutierrez C, Chaparro C, Hutcheon MA, Chan CK. Osteoporosis and lung transplantation: a prospective study. Chest. 2000;117:476-81.

11. Robertson J, Macdonald K. Prevalence of bone loss in a population with cystic fibrosis. Br J Nurs. 2010;19:636-9.

12. Dodd JD, Barry SC, Barry RB, Cawood TJ, McKenna MJ, Gallagher CG. Bone mineral density in cystic fibrosis: benefit of exercise capacity. J Clin Densitom. 2008;11:537-42.

13. Street ME, Spaggiari C, Ziveri MA, Volta C, Federico G, Baroncelli GI, et al. Analysis of bone mineral density and turnover in patients with cystic fibrosis: associations between the IGF system and inflammatory cytokines. Horm Res. 2006;66:162-8

14. King SJ, Topliss DJ, Kotsimbos T, Nyulasi IB, Bailey M, Ebeling PR, et al. Reduced bone density in cystic fibrosis: DeltaF508 mutation is an independent risk factor. Eur Respir J. 2005;25:54-61.

15. Frangolias DD, Pare PD, Kendler DL, Davidson AG, Wong L, Raboud J, et al. Role of exercise and nutrition status on bone mineral density in cystic fibrosis. J Cyst Fibros. 2003;2:163-70.

16. Bachrach LK, Loutit CW, Moss RB. Osteopenia in adults with cystic fibrosis. Am J Med. 1994;96:27-34.

17. Douros K, Loukou I, Nicolaidou P, Tzonou A, Doudounakis S. Bone mass density and associated factors in cystic fibrosis patients of young age. J Paediatr Child Health. 2008;44:681-5.

18. Cemlyn-Jones J, Gamboa F, Loureiro M, Fontes Baganha M. Evaluation of bone mineral density in cystic fibrosis patients. Rev Port Pneumol. 2008; 14:625-34.

19. Haworth CS, Selby PL, Webb AK, Martin L, Elborn JS, Sharples LD, et al. Inflammatory related changes in bone mineral content in adults with cystic fibrosis. Thorax. 2004;59:613-7.

20. Donovan DS Jr, Papadopoulos A, Staron RB, Addesso V, Schulman L, $\mathrm{McGregor} \mathrm{C}$, et al. Bone mass and vitamin D deficiency in adults with 
advanced cystic fibrosis lung disease. Am J Respir Crit Care Med. 1998;157:1892-9.

21. O’Reilly R, Fitzpatrick P, Leen G, Elnazir B, Greally P. Severe bone demineralisation is associated with higher mortality in children with cystic fibrosis. Ir Med J. 2009;102:47-9.

22. Flohr F, Lutz A, App EM, Matthys H, Reincke M. Bone mineral density and quantitative ultrasound in adults with cystic fibrosis. Eur J Endocrinol. 2002;146:531-6.

23. Conway SP, Morton AM, Oldroyd B, Truscott JG, White H, Smith AH, et al. Osteoporosis and osteopenia in adults and adolescents with cystic fibrosis: prevalence and associated factors. Thorax. 2000;55:798-804.

24. Caldeira RJ, Fonseca VM, Gomes SC Jr, Chaves CR. Prevalence of bone mineral disease among adolescents with cystic fibrosis. J Pediatr (Rio J). 2008;84:18-25

25. Cauley JA, Lui LY, Ensrud KE, Zmuda JM, Stone KL, Hochberg MC, et al. Bone mineral density and the risk of incident nonspinal fractures in black and white women. JAMA. 2005;293:2102-8.

26. Bobadilla JL, Macek M Jr, Fine JP, Farrell PM. Cystic fibrosis: a worldwide analysis of CFTR mutations--correlation with incidence data and application to screening. Hum Mutat. 2002;19:575-606.

27. Streit C, Burlamaque-Neto AC, Abreu e Silva F, Giugliani R, Saraiva Pereira ML. CFTR gene: molecular analysis in patients from South Brazil. Mol Genet Metab. 2003;78:259-64.

28. ISCD: The ISCD's official positions (updated 2007); Washington (DC): International Society for Clinical Densitometry; 2007.

29. WHO: Scientific group on the assessment of osteoporosis at primary health care level: Sumary Meeting Report Brussels, Belgium; 2004.

30. Borowitz D, Baker RD, Stallings V. Consensus report on nutrition for pediatric patients with cystic fibrosis. J Pediatr Gastroenterol Nutr. 2002;35:246-59.

31. Stallings VA, Stark LJ, Robinson KA, Feranchak AP, Quinton H. Evidencebased practice recommendations for nutrition-related management of children and adults with cystic fibrosis and pancreatic insufficiency: results of a systematic review. J Am Diet Assoc. 2008;108:832-9.

32. Pereira CA, Sato T, Rodrigues SC. New reference values for forced spirometry in white adults in Brazil. J Bras Pneumol. 2007;33:397-406.
33. Shwachman H, Kulczycki LL. Long-term study of one hundred five patients with cystic fibrosis; studies made over a five- to fourteen-year period. AMA J Dis Child. 1958;96:6-15.

34. Brasfield D, Hicks G, Soong S, Tiller RE. The chest roentgenogram in cystic fibrosis: a new scoring system. Pediatrics. 1979;63:24-9.

35. Baim S, Leonard MB, Bianchi M. American College of Radiology. Practice guideline for the performance of dual-energy $\mathrm{x}$-ray absorptiometry (DXA). 2008 [cited 2012 Apr 15]. Available from: http://www.acr.org.

36. Baim S, Binkley N, Bilezikian JP, Kendler DL, Hans DB, Lewiecki EM, et al. Official Positions of the International Society for Clinical Densitometry and executive summary of the 2007 ISCD Position Development Conference. J Clin Densitom. 2008;11:75-91.

37. Lucidi V, Bizzarri C, Alghisi F, Bella S, Russo B, Ubertini G, Cappa M. Bone and body composition analyzed by Dual-energy X-ray Absorptiometry (DXA) in clinical and nutritional evaluation of young patients with Cystic Fibrosis: a cross-sectional study. BMC Pediatr. 2009;9:61.

38. Bianchi ML, Romano G, Saraifoger S, Costantini D, Limonta C, Colombo $\mathrm{BMD}$ and body composition in children and young patients affected by cystic fibrosis. J Bone Miner Res. 2006;21:388-96.

39. Buntain HM, Greer RM, Schluter PJ, Wong JC, Batch JA, Potter JM, et al. Bone mineral density in Australian children, adolescents and adults with cystic fibrosis: a controlled cross sectional study. Thorax. 2004;59:149-55.

40. Haworth CS, Selby PL, Webb AK, Dodd ME, Musson H, Mc LNR, et al. Low bone mineral density in adults with cystic fibrosis. Thorax. 1999;54:961-7.

41. Bhudhikanok GS, Lim J, Marcus R, Harkins A, Moss RB, Bachrach LK. Correlates of osteopenia in patients with cystic fibrosis. Pediatrics. 1996;97:103-11.

42. Stephenson A, Jamal S, Dowdell T, Pearce D, Corey M, Tullis E. Prevalence of vertebral fractures in adults with cystic fibrosis and their relationship to bone mineral density. Chest. 2006;130:539-44

43. Gennari L, Nuti R, Bilezikian JP. Aromatase activity and bone homeostasis in men. J Clin Endocrinol Metab. 2004;89:5898-907.

44. Leib ES, Saag KG, Adachi JD, Geusens PP, Binkley N, McCloskey EV, et al. Official Positions for FRAX ${ }^{\circledR}$ clinical regarding glucocorticoids: the impact of the use of glucocorticoids on the estimate by FRAX ${ }^{\circledR}$ of the 10 year risk of fracture from Joint Official Positions Development Conference of the International Society for Clinical Densitometry and International Osteoporosis Foundation on FRAX®. J Clin Densitom. 2011;14:212-9. 